\title{
Çanakkale İli Ispanak Üretim Alanlarında Pancar Nekrotik Sarı Damar Virüsü (Beet Necrotic Yellow Vein Virus; BNYVV)'nün Tespiti ve Moleküler Karakterizasyonu
}

\author{
Zeynep Bağlan ${ }^{1}$, Savaş Korkmaz $^{1}$ * \\ ${ }^{1}$ Çanakkale Onsekiz Mart Üniversitesi, Ziraat Fakültesi, Bitki Koruma Bölümü
}

03.09.2019 Geliş/Received, 10.10.2019 Kabul/Accepted

$\ddot{O} \mathbf{z}$

Ispanak önemli bir kışlık sebze olup ülkemizin her bölgesinde üretimi yapılmaktadır. Ispanak üretiminde verim ve kaliteyi etkileyen birçok hastalık etmeni vardır ve bunlar içerisinden virüsler önemli bir yer tutmaktadır. Bu virüs hastalıklarından bir tanesi "Rhizomonia" olarak ta adlandırılan Pancar nekrotik sarı damar virüsü (Beet necrotic yellow vein virus; BNYVV)'dür. BNYVV'nin ülkemizde 1spanak bitkisinde varlığı serolojik yöntemlerle belirlenmiş ancak moleküler düzeyde bir çalışma yapılmamıştır. Bu amaçla Çanakkale'de il ve ilçe düzeyinde 1 spanak yetiştiriciliği yapılan alanlara BNYVV'nin varlığını belirlemek ve tanısını yapmak amacı ile 2017-2018 üretim yılında bir arazi çalışması gerçekleştirilmiştir. Bu arazi çalışması kapsamında tipik virüs simptomları gösteren 1spanak bitkilerinden 66 örnek alınmıştır. Alınan örneklerdeki BNYVV varlığı virüs proteinine dayalı bir yöntem olan DASELISA testi ile belirlenmiştir. DAS-ELISA testi sonuçlarına göre 66 örneğin 12'si BNYVV ile enfekteli bulunmuştur. Enfekteli bulunan örnekler içerisinden bir tanesi seçilerek (CNKSpinach39) örtü protein geni (coat protein; CP) RT-PCR ile çoğaltılmıştır. CP geni çoğaltılan izolatın RT-PCR ürünleri saflaştırılmış ve nükleotid dizileri belirlenmiştir. Elde edilen nükleotit (nt) dizileri kullanılarak seçilen izolata ait $\mathrm{CP}$ geninin amino asit (aa) dizileri çıkarılmıştır. Bu nükleotid ve amino asit dizileri dünya BNYVV izolatlarının $\mathrm{CP}$ genlerinin nükleotid ve amino asit dizileri ile karşılaştırılarak, göstermiş oldukları benzerlik oranları ve filogenetik ilişkileri saptanmıştır. Gerçekleştirilen çoklu nt ve aa temelli dizi karşılaştırmaları sonucunda CNKSpinach39 izolatının dünya izolatları ile \%95-99 oranında benzerlikler gösterdiği belirlenmiştir. Gerçekleştirilen filogenetik analizler sonucunda ise CNKSpinach39 izolatının B patotipinde yer aldığı tespit edilmiştir. Bu çalışma ile ülkemizde ispanakta ilk defa BNYVV'nin B patotipi bulunmuştur.

Anahtar Kelimeler: PCR, benzerlik, filogenetik, 1spanak, BNYVV

*Sorumlu Yazar (Corresponding Author): Savaş Korkmaz

(e-posta: skorkmaz@comu.edu.tr)

Bu makale Zeynep Bağlan'ın tez konusu kapsamında yazılmıştır.

ÇOMÜ BAP Koordinasyon Birimince desteklenmiştir. Proje numarası: FYL-2018-2545 


\title{
Detection and Molecular Characterization of Beet Necrotic Yellow Vein Virus (BNYVV) in Spinach Production Fields of Çanakkale Province, Turkey
}

\begin{abstract}
Spinach is an important winter vegetable and it is produced in all regions in Turkey. There are many diseases affecting the yield and quality in its production. Viruses have an important role among them. One of these virus diseases is Beet necrotic yellow vein virus (BNYVV), called Rhizomania disease. The presence of BNYVV in the spinach plant was determined by serological methods in Turkey, but no studies were conducted at the molecular level. For this purpose, field studies were carried out in 2017-2018 in order to determine the presence of BNYVV in the fields of spinach cultivation at the level of Çanakkale province and its districts. In these field studies, 66 samples were collected from spinach plants showing typical virus symptoms. The presence of BNYVV in the samples was determined by DAS-ELISA test, a method based on virus protein. According to the DAS-ELISA test, 12 out of 66 samples were infected with BNYVV. One of the infected samples was selected (CNKSpinach39) and the coat protein gene (CP) was amplified by RT-PCR. Its RT-PCR product was purified and sequenced. The amino acid (aa) sequences of this isolate was deduced based on its nt sequence. These nt and aa sequences were compared with the related sequences of the world BNYVV isolates and their similarities and phylogenetic relationships were determined. As a result of multiple sequence comparisons based on nt and aa, it was determined that CNKSpinach39 isolates showed similarities with $95-99 \%$ of the world isolates. As a result of the phylogenetic analysis, it was determined that the isolate CNKSpinach39 was found in the B pathotype. In this study, the first BNYVV B pathotype was found in spinach in our country.
\end{abstract}

Keywords: PCR, similarity, phylogenetic, spinach, BNYVV

\section{Giriş}

Ülkemizde yetiştiriciliği yapılan ve yaprăğ yenen sebzelerden bir tanesi de ispanaktır. Ispanakta hastalık ve zarar oluşturan birçok organizma vardır. $\mathrm{Bu}$ hastalık ve zararlılar ıspanak üretimini azaltmakta ve pazarlama değerini düşürmektedir. Bu hastalık ve zararlılar içerisinde etkin bir mücadele yönteminin olmaması nedeni ile virüs ve benzeri hastalıklar ayrı bir öneme sahiptir.

Virüslerin bitkilerde hastalık oluşturmasında yayılma yolları önem taşımaktadır. Bu taşınma yolları; mekanik yayılma, tohumla yayılma, aşı yoluyla yayılma, küskütle yayılma, vejetatif çoğalma materyali ile yayılma, toprakla yayılma, vektörlerle yayılma (böceklerle yayılma, nematodlarla yayılma, funguslarla yayılma) olarak sıralanabilmektedir. Bu şekillerde bitkiler arasında taşınarak neden oldukları ekonomik kayıpların miktarı artabilmektedir.

Bugüne kadar gerçekleştirilen çalışmalar kapsamında 1spanakta ekonomik düzeyde zarar oluşturan birçok virüs hastalığı tanımlanmıştır. Bu virüs hastalıkları arasından BNYVV toprak kökenli bir vektör tarafından taşınmasından dolayı diğerlerine göre farklı bir önem arz etmektedir. BNYVV enfeksiyonları sonucu özellikle etmenin ana konukçusu olan şekerpancarı bitkilerinin lateral köklerinde büyük bir oranda artış gözlenmektedir ve bu tipik belirtiden dolayı etmene kök azmanlığı anlamına gelen "Rhizomania hastalığı" denilmektedir (Putz ve ark., 1990). 
Rhizomania özellikle şeker pancarında hastalık oluşturan bir virüs olmakla birlikte son yıllarda ülkemizde 1spanakta da hastalık oluşturduğu da rapor edilmiştir (Gümüş ve ark., 2014; Karanfil ve ark., 2016). Virüsün taşınmasında obligat parazitik bir fungus olan Polymyxa betae (Keskin) büyük bir öneme sahiptir. Viral etmen, Tubiviridae familyasından Benyvirus cinsine dahildir (Lennofors, 2006). Hastalık etmeni $20 \mathrm{~nm}$ eninde farklı boyutlarda ve çubuk şekilli partiküllere sahiptir. Virüs tek sarmal 4 parçalı RNA genomundan oluşmaktadır. Ancak bazı izolatlarda bu 4 parçalı RNA genomuna ek olarak 5. bir RNA genomu içerdiğinden de bahsedilmektedir (Koenig ve ark., 1997; Koenig ve Lennefors, 2000; Harju ve ark., 2002). BNYVV enfekteli bitkilerin yapraklarında, damar boyunca uzanan sarımtırak renk açılmaları ve yaprakların dikine gelişim gösterdiği belirtilmektedir. Hastalığın ilerlemesi ile de belirtilen sarımtırak renk değişimlerinin nekrotik alanlara dönüştüğü bilinmektedir (Whitney ve Duffus, 1991).

BNYVV'nin bugüne kadar gerçekleştirilen çalışmalar sonucunda etmenin dünyada 4 farklı patotip olarak gruplandırıldığı görülmektedir (Kruse ve ark., 1994). Bu gruplardan A tipi kuzey batı ve güney Avrupa'da, B tipi ise Fransa ve Almanya'da belirlenmiştir. Ülkemizde ise çoğunlukla görülen tipin ise A olduğu belirtilmiştir (Özgör, 1995). A ve B tipine göre daha şiddetli ve saldırgan olarak nitelendirilen $\mathrm{P}$ ve $\mathrm{J}$ olmak üzere 2 patotip daha mevcuttur. $\mathrm{Bu}$ patotiplerden $\mathrm{P}$ tipinin varlığı ise Kazakistan ve Fransa'dan bildirilmiştir (Koenig ve Lennefors, 2000). Patotip J'nin varlığı ise Japonya, Çin ve ülkemizden bildirilmiştir (Tamada ve ark., 1989; Li ve ark., 2008a; Kutluk-Y1lmaz ve ark., 2016a). Bu patotiplerden P ve J diğer patotiplere göre fazladan bir RNA segmentine sahiptir.

BNYVV'nin konukçu genişliği nispeten dardır. Hastalık etmeni ıspanakta çoğunlukla sistemik bir şekilde bulunabilmektedir (Tamada ve Baba, 1973; Y1lmaz ve Erkan, 2003). Etmenin arazide yapraklara ait simptomlarının anlaşılması zordur. Genellikle besin elementi noksanlıkları ile karıştırılmaktadır (Rush ve Heidel, 1995). Şiddetli enfeksiyonlarda yapraklar solmaktadır. Etmene ismini veren nekrotik sarı damar belirtisine ise doğada kendiliğinden gelişen enfeksiyonlarda pek sik rastlanmamaktadır. Erken dönemlerinde etmen tarafindan enfekte edilen bitkilerde tipik belirtiler gözlenebilmektedir. Bitkilerdeki kök gelişimi neredeyse tamamen yan kök oluşumu şeklinde olmaktadır. Oluşan bu lateral kökler de sonradan etmen tarafından enfekte edilerek, köklerin ölümü gerçekleşmektedir. Bitkilerin devamlı olarak lateral kök oluşturması nedeniyle bitki kökleri sakal görünümüne dönüşmektedir (Rush ve Heidel, 1995).

BNYVV doğada toprak kökenli bir fungal vektör olan $P$. betae'nın kalın çeperli kışlama sporlarında 15 yıl canlı kalabildiği ve fungus bünyesine giren etmenin uzun süre taşınabildiği belirtilmiştir (Abe ve Tamada, 1986). Toprak neminin az olduğu durumlar ve uygun olmayan sıcaklık derecelerinde, $P$. betae'nın neden olduğu rhizomonia enfeksiyonları bitkilerin daha ileri dönemlerinde görülebilmektedir. $\mathrm{Bu}$ şekilde oluşan hastalık gelişimleri de ürün kayılarını azaltabilmektedir (Putz ve ark., 1990).

Bugüne kadar hem dünyada hem de ülkemizde yapılan çalışmalar kapsamında ispanak üretim alanlarında BNYVV enfeksiyonu tespit edilmiştir (Erbay, 2012; Karanfil ve ark., 2016; Kutluk-Yılmaz ve ark., 2016b). Özellikle ülkemiz şeker pancarı BNYVV izolatlarının moleküler karakterizasyonları gerçekleştirilmesine rağmen, 1spanak üretim alanlarında enfeksiyon oluşturan BNYVV izolatlarının moleküler karakterizasyonu ise gerçekleştirilmemiştir (Kutluk-Yılmaz ve ark., 2016a; 2016b). Bu bağlamda bu çalışma kapsamında ülkemiz ıspanak BNYVV izolatlatlarının moleküler karakterizasyonlarının gerçekleştirilmesi amacı ile planlanmıştır. Yapılan bu çalışma ile ülkemiz ıspanak üretim 
alanlarından elde edilen BNYVV izolatının ilk kez moleküler karakterizasyonu gerçekleştirilerek dünya izolatları ile nükleotid ve amino asit düzeyindeki benzerlik ve farklılık oranları ortaya konmuştur. Ayrıca gerçekleştirilen filogenetik çalışmalar ile de dünya izolatları ile gösterdiği farklı akrabalık dereceleri saptanmıştır.

\section{Materyal ve Yöntem}

$\mathrm{Bu}$ araştırma kapsamında gerçekleştirilen çalışmalar temel olarak 4 aşamada yürütülmüştür. Çalışmanın ilk aşamasında Çanakkale ili ve ilçelerinde bir arazi çalışması yürütülerek ıspanak tarlalarında virüs ve virüs benzeri simptom gösteren bitkilerden toplam 66 örnek toplanmıştır. İkinci aşamada toplanan örneklerde BNYVV'nin varlı̆̆ı DAS-ELISA yöntemi ile testlenmiştir. Üçüncü aşamada DAS-ELISA testi sonuçları pozitif olan örneklerin RT-PCR ile testlemesi yapılmış ve elde edilen RT-PCR ürünleri kullanılarak seçilen bir izolatın (CNKSpinach39) nükleotid dizileri hizmet alımı ile belirlenmiştir. Son aşamada ise elde edilen BNYVV CP (coat protein; kılıf protein) genlerine ait nükleotid dizilimleri kullanılarak, amino asit dizilimleri çıkarılmıştır. Elde edilen bu diziler kullanılarak dünya BNYVV izolatları ile Çanakkale ıspanak izolatının moleküler ilişkileri araştırılmıştır.

\subsection{Arazi Çalışması}

Arazi çalışması 2017-2018 yıllarında Amaranthaceae familyasına ait 1spanak bitkisinin yetiştiriciliğinin yapıldığı Çanakkale ili ve ilçelerinde yürütülmüştür. Üretim sezonu süresince Çanakkale ili ve ilçelerinde yetiştirilen 1spanak bitkileri görsel olarak incelenerek BNYVV belirtilerine benzer belirti gösteren bitkilerden örnekler alınmıştır. Örnekleme yapılan alanların seçimi tamamen tesadüfi olarak gerçekleştirilmiştir. Toplanan örnekler soğuk zincirde muhafaza edilerek laboratuvara getirilmiş ve ileri analizlerin yapılması için $4^{0} \mathrm{C}^{\prime} \mathrm{de}$ silika jel içinde saklanmıștır.

\subsection{Virüs Tanılama Çalışmaları}

Gerçekleştirilen arazi çalışmaları sonucunda virüs ve virüs benzeri hastalık ile enfekteli olduğundan şüphelenilerek toplanan örneklerdeki BNYVV varlığı serolojiye dayalı bir yöntem olan DAS-ELISA testi ile Clark ve Adams (1997)'ın belirttiği yöntem esas alınarak kitlerin sağlandığ1 firmanın (Bioreba, İsviçre) önerileri doğrultusunda gerçekleştirilmiştir. Sonuçlar MEDISPEC ESR 200 ELISA okuyucusunda $405 \mathrm{~nm}$ dalga boyunda okuma işlemine tabi tutulmuş ve absorbans değerleri belirlenmiştir. Absorbans değerlerine göre negatif kontrolün iki katı ve üzerindeki değerlere sahip olan örnekler BNYVV ile enfekteli olarak kabul edilmiştir.

\subsection{Moleküler Karakterizasyon Çalışmaları}

DAS-ELISA test sonuçlarına göre BNYVV ile enfekteli olan örneklerin RT-PCR ile moleküler karakterizasyonlarının yapılabilmesi için hedef gen bölgelerinin amplifikasyonu gerçekleştirilmiştir. RT-PCR analizlerine total RNA izolasyonu ile başlanmıştır. Total RNA izolasyonu Li ve ark., (2008b)'nın belirttiği şekilde CTAB metodu ile gerçekleştirilmiştir. RT-PCR aşaması kitlerin sağlandığı firmanın (Qiagen, Kanada) belirttiği şekilde BNYVV gen spesifik primer ile gerçekleştirilmiştir (Çizelge 2.1 ve 2.2). 
Çizelge 2.1. Çalışma kapsamında kullanılan primer çifti, dizisi ve gen bölgesi

\begin{tabular}{|c|c|c|c|c|}
\hline Kodu & Dizisi & Yönü & $\begin{array}{c}\text { Hedef Gen } \\
\text { Bölgesi }\end{array}$ & Referans \\
\hline BN2/F1 & ATGTCGAGTGAAGGTAGATATATG & İleri & $\begin{array}{c}\text { Killf Protein } \\
\text { Geni (567 bç) }\end{array}$ & $\begin{array}{c}\text { Schirmer et } \\
\text { al. (2005) }\end{array}$ \\
BN2/R3 & ATTGTCCGGGTGGACTGGTTC & Geri & & \\
\hline
\end{tabular}

Son aşamada agaroz jel elektroforezi ile elde edilen RT-PCR ürünleri 100-1000 bp DNA büyüklük markörleriyle birlikte $\% 1.5^{\prime}$ lik agaroz jelinde 100 voltta ayrıştırılıp EtBr ile boyandıktan sonra ultraviyole 1şı altında Major Science UVDI jel görüntüleme cihazında BNYVV'nin kılıf proteinine ait bantlar fotoğraflanmıştır.

Çizelge 2.2. RT-PCR testlerinde kullanılan bileşenler, miktarları ve RT-PCR koşulları

\begin{tabular}{|c|c|c|c|}
\hline Bileşenler & Hacim & \multicolumn{2}{|c|}{ RT-PCR Koşulları } \\
\hline RNase-free water & \multirow{7}{*}{$\begin{array}{c}13 \mu \mathrm{l} \\
5 \mu \mathrm{l} \\
1 \mu \mathrm{l} \\
1 \mu \mathrm{l} \\
1 \mu \mathrm{l} \\
1 \mu \mathrm{l} \\
3 \mu \mathrm{l} \\
\end{array}$} & \multirow{4}{*}{\multicolumn{2}{|c|}{$\begin{array}{l}\text { 1. } 30 \mathrm{dk}-50^{\circ} \mathrm{C} \\
\text { 2. } 15 \mathrm{dk}-95^{\circ} \mathrm{C}\end{array}$}} \\
\hline 5x QIAGEN OneStep RT-PCR Buffer & & & \\
\hline dNTP Mix (containing $10 \mathrm{mM}$ of each dNTP) & & & \\
\hline Primer Karışımı (Forward-Reverse) & & & \\
\hline QIAGEN OneStep RT-PCR Enzyme Mix & & \multirow{3}{*}{$\begin{array}{l}\text { 3. } 94^{\circ} \mathrm{C}-1 \mathrm{dk} \\
\text { 4. } 59^{\circ} \mathrm{C}-1 \mathrm{dk} \\
\text { 5. } 72^{\circ} \mathrm{C}-45 \mathrm{dk}\end{array}$} & \multirow{3}{*}{39 Döngü } \\
\hline RNase inhibitor & & & \\
\hline Total RNA & & & \\
\hline Toplam Hacim & $25 \mu 1$ & $\begin{array}{l}6.72^{\circ} \mathrm{C}-10 \mathrm{dk} \\
7.10^{\circ} \mathrm{C}-\text { süresiz }\end{array}$ & \\
\hline
\end{tabular}

RT-PCR ile çoğaltılmış BNYVV CP genlerine ait bir izolatın (CNKSpinach39) RT-PCR ürünü E.Z.N.A PCR pürifikasyon kiti (Omega Bio, ABD) kullanılarak üretici firmanın önerileri doğrultusunda saflaştırma işlemine tabi tutulmuştur. Saflaştırılan RT-PCR ürününün DNA baz dizilimleri hizmet alımı ile belirlenmiştir.

Elde edilen CNKSpinach39 BNYVV izolatının CP geninin nükleotit dizileri, daha önceden dizilimi belirlenerek gen bankalarına konulmuş dünyanın farklı bölgelerine ait BNYVV izolatlarının (Çizelge 2.3) kılıf protein genlerinin nükleotit dizileriyle bir araya getirildikten sonra Sequence Demarcation Tool, version 1.2 (SDTv1.2) programı kullanılarak benzerlik oranları ortaya konulmuştur (Muhire ve ark., 2014). Ayrıca dünya ve CNKSpinach39 BNYVV izolatları arasındaki filogenetik ilişkiler Neighbor-joining metoduyla kiamura iki algoritması uygulanarak 1000 tekrarlı bootstrap analizi ile belirlenmiştir. Oluşturulan filogenetik ağaçlarda Beet soil-borne mosaic virus; BSBMV (Genbankası erişim no: JF513083) dış grup olarak filogenetik ağacın doğruluğunu arttırmak amacı ile kullanılmıştır. Filogenetik analizler Mega7 programında gerçekleştirilmiştir (Kumar ve ark., 2016). 
Çizelge 2.3. Çanakkale ili ıspanak üretim alanlarından elde edilen CNKSpinach39 Pancar nekrotik sarı damar virüsü'nün moleküler karakterizasyonu amacı ile gerçekleştirilen çoklu dizi ve filogenetik analizlerde kullanılan dünya izolatları, patotipler ve erişim numaraları

\begin{tabular}{|c|c|c|c|c|}
\hline Ülke & İzolat & Patotip & Erişim Numaras1 & Referans \\
\hline Çin & Wu2 & A & EF473095 & Li ve ark., 2008a \\
Çin & YJZCP-4 & A & KP316636 & Zhou ve ark., 2015 \\
Çin & GZCCP-3 & A & KP316623 & Zhou ve ark., 2015 \\
Slovakya & SLN1 & A & AB563019 & Chiba ve ark., 2011 \\
Türkiye & TUK & A & AB563026 & Chiba ve ark., 2011 \\
İtalya & IV4 & A & AB563002 & Chiba ve ark., 2011 \\
Avusturya & A2 & A & AY696072 & Schirmer ve ark., 2005 \\
Belçika & B3 & B & AY696079 & Schirmer ve ark., 2005 \\
Belçika & Rutten & B & AJ634737 & Meunier ve ark., 2005 \\
Almanya & GT85 & B & AJ810284 & Lennefors ve ark., 2005 \\
Çin & BTCP-9 & B & KP316557 & Zhou ve ark., 2015 \\
Japonya & S44 & B & AB018624 & Miyanishi ve ark., 1999 \\
Çin & IMHHCP-3 & B & KP006486 & Zhou ve ark., 2015 \\
Çin & Hoh2 & B & EF473092 & Li ve ark., 2008a \\
Çin & CH6 & B & AB562989 & Chiba ve ark., 2011 \\
\hline
\end{tabular}

\section{Bulgular ve Tartışma}

\subsection{Arazi ve Virüs Tanılama Çalışmaları}

Çanakkale ili ve ilçelerinde gerçekleştirilen arazi çalışmaları kapsamında BNYVV veya virüs benzeri belirti taşıyan toplam 66 sspanak örneği toplanmıştır. (Çizelge 3.1). Çanakkale Merkez ile birlikte toplam 7 ilçede örnekleme yapılmış ve en çok örnekleme 23 örnek ile Merkez ilçede yapılırken en az örnekleme ise 3 örnek ile Ezine ilçesinden yapılmıştır.

Gerçekleştirilen DAS-ELISA ile BNYVV enfeksiyonu tanılama çalışmaları sonucunda toplanan 66 örneğin 12'si BNYVV ile enfekteli olarak bulunmuştur. En fazla örnekleme yapılan Merkez ilçeden toplanan 23 örneğin 7'sinde BNYVV tespit edilmiştir. Merkez ilçenin dışında Çan'dan toplanan 7 örneğin 2'si, Bayramiç'ten toplanan 4 örneğin 2'si ve Ayvacık'tan toplanan 5 örneğin 1'i BNYVV ile enfekteli bulunmuştur. En fazla örnek toplanan ikinci ilçe (toplam 16 örnek) Biga'da ise enfekteli örnek bulunamamıştır. Ayrıca diğer ilçelerden Lapseki ve Ezine'de de enfekteli örnek bulunamamıştır. Toplanan örneklerde enfeksiyon oranına bakıldığında Bayramiç'ten toplanan 4 örneğin 2'si enfekteli bulunmuş ve oran \% 50,00 olarak gerçekleşmiştir. Bunu sırasıyla Merkez ilçe $(\% 30,43)$, Çan $(28,57)$ ve Ayvacık $(\% 20,00)$ ilçeleri izlemiştir. Toplam enfeksiyon oranı ise \%18,18 olarak saptanmıştır (Çizelge 3.1). 
Çizelge 3.1. Çanakkale ili ve ilçelerinden toplanan ve Pancar nekrotik sarı damar virüsü ile enfekteli bulunan örnek sayıları ile enfeksiyon oranları

\begin{tabular}{|c|c|c|}
\hline İlçeler & Enfekteli Örnek/Toplanan Örnek & Toplanan Örneklerdeki Enfeksiyon Oranı (\%) \\
\hline Merkez & $7 / 23$ & 30,43 \\
\hline Ayvacık & $1 / 5$ & 20,00 \\
\hline Çan & $2 / 7$ & 28,57 \\
\hline Biga & $0 / 16$ & 0 \\
\hline Lapseki & $0 / 8$ & 50,00 \\
\hline Bayramiç & $2 / 4$ & 0 \\
\hline Ezine & $0 / 3$ & 18,18 \\
\hline Toplam & $12 / 66$ & \\
\hline
\end{tabular}

Genel olarak Çanakkale ili ve ilçelerinde bazen küçük tarlalar şeklinde olsa bile yaygın olarak ıspanak tarımı yapılmaktadır. Ancak örneklemenin yapıldığ 1 yıllarda genel olarak ispanak tarımı yapılan alanların dağılımında bir dalgalanma olduğu için ilçelerden yapılan örnekleme sayıları arasında farklılıklar meydana gelmiştir. Ayrıca Çanakkale il ve ilçelerinde çok sayıda ıspanak tarlalarına çıkış yapılmış ancak bazı tarlalarda simptom görülmemesi nedeniyle örnek toplanmamıştır.

Arazi çalışmaları kapsamında ıspanaklarda genel olarak sararma, bodurlaşma, yapraklarda mozaik belirtileri, besin elementi noksanlığına benzer belirtiler, yaprak damarlarında kalınlaşma ile birlikte sarımtırak renk oluşumu simptomları gözlenmiştir. DAS-ELISA testlemeleri sonucunda bu belirtilerden bodurlaşma, mozaik belirtisi ve besin elementi noksanlığı belirtisi simptomları gösterenler BNYVV için genellikle negatif sonuç verirken sararma ve damarlarda kalınlaşma simptomu gösterenler pozitif sonuç vermiştir. Bununla birlikte çok hafif virüs benzeri simptom gösteren bazı bitkiler de enfekteli olarak bulunmuştur. Şekil 3.1'de virüs tanılama çalışmalarında BNYVV ile enfekteli olarak bulunan 1spanak bitkilerindeki belirtiler görülmektedir. Bu belirtiler bitkinin yaprak damarlarında hafif bir kalınlaşma ve sarımtırak renk oluşumu şeklinde görülmekte olup Şekil 3.1 de yuvarlak bir çerçeveye alınarak ok ile belirtilmiştir.

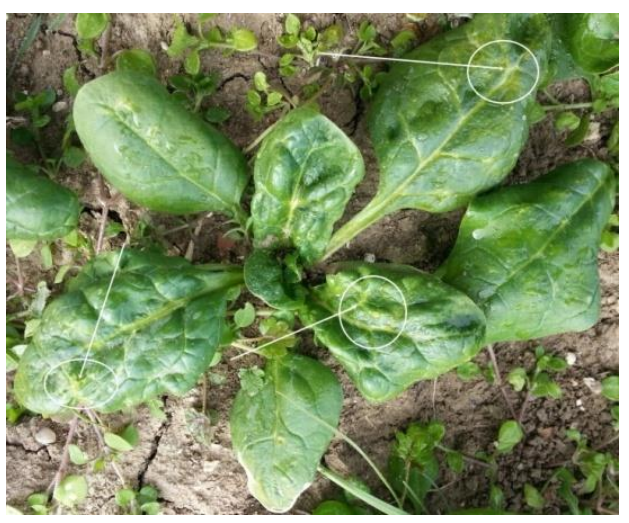

Şekil 3.1. Pancar nekrotik sarı damar virüsü ile enfekteli ıspanak bitkisinin yapraklarında meydana gelen hastalık belirtileri 
$\mathrm{Bu}$ çalışma kapsamında toplanan 66 örneğin sadece 12'si BNYVV ile enfekteli olarak bulunmuştur. Diğer örnekler tipik virüs ve virüs benzeri simptom göstermesine rağmen BNYVV için negatif çıkmıştır. Bunun en önemli nedeni bu bitkilerin diğer virüslerle enfekteli olabileceğidir. Ispanakta BNYVV yanında gerek ülkemizde gerekse dünyada birçok virüsün enfeksiyon yaptığı bilinmektedir. Ülkemizde Ege Bölgesinde (Gediz havzası) 1spanak yetiştiriciliği yapılan alanlarda yapılan bir çalışmada şekil bozukluğu, klorotik lekeler, yapraklarda kıvrılma, mozaik, gelişme geriliği ve damar aralarında sararma belirtisi gösteren bitkilerden örnekler toplanmış ve RT-PCR ile testlenmiştir. Testlemeler sonucunda BNYVV, CMV, TMV, BWYV ve TuMV infeksiyonlarını tespit edilmiştir (Erbay, 2012). Çanakkale ili sspanak üretim alanlarında gerçekleştirilen bir başka çalışmada ise CMV ve TuMV etmenlerinin varlığı saptanmıştır (Gökdağ ve ark., 2016). Samsun ili 1spanak üretim alanlarında gerçekleştirilen bir başka çalışmada da CMV ve TuMV enfeksiyonu belirlenmiştir (Güngör ve ark., 2017). Yapılan bu çalışmalar ülkemizde ıspanak bitkisinde BNYVV'nin dışında birçok virüsün enfeksiyon yaptığını göstermektedir.

Hastalığın yaygınlık durumu ile ilgili Çanakkale ili ve ilçelerinde ıspanak üretim tarlalarında 2013 ve 2015 yılı üretim sezonlarında gerçekleştirilen benzer bir çalışmada araştırmacılar topladıkları 52 örneğin 18'inin BNYVV ile enfekteli olduğunu bildirmişlerdir (Karanfil ve ark., 2016). Araştırmacıların gerçekleştirdikleri çalışma ile bu çalışmanın sonuçları birbirleri ile benzerlik göstermekte olup, Çanakkale'deki 1spanak üretim alanlarında BNYVV enfeksiyonunun yaygın olduğu görülmektedir. Benzer şekilde Samsun ilinde gerçekleştirilen başka bir çalışmada da 1spanak alanlarında BNYVV enfeksiyonuna rastlanıldığ (Kutluk-Yılmaz ve ark., 2016b). Farklı bölgelerde gerçekleştirilen bu çalışmalardan da anlaşılacağı üzere ülkemiz ıspanak üretim alanlarında BNYVV enfeksiyonunun yaygın olarak meydana geldiği söylenebilir.

\subsection{Moleküler Karakterizasyon Çalışmaları}

DAS-ELISA testleri sonucu BNYVV ile enfekteli olarak bulunan 4 izolatın RT-PCR ile CP genleri çoğaltılmış ve seçilen bir izolatın (CNKSpinach39) hizmet alımı yolu ile sekans dizileri çift yönlü olarak belirlenmiştir. Elde edilen ham sekans verileri birleştirilerek BNYVV CP genine karşılık gelen 567 bç büyüklüğünde nükleotit (nt) sekans verisi elde edilmiştir. Elde edilen bu sekans verileri kullanarak CNKSpinach39 izolatının CP geninin kodladığı amino asit (aa) dizilimleri ortaya çıkarılmıştır. Dünyada da BNYVV izolatlarının moleküler karakterizasyonu amacı ile kullanılan gen bölgelerinden bir tanesinin de CP geni olduğu bilinmektedir (Borodynko ve ark., 2009; Lennofors ve ark., 2005).

Dünya izolatları ile gerçekleştirilen karşılaştırmalı nt ve aa dizi analizleri ile CNKSpinach39 izolatının dünya izolatları ile nt düzeyinde \%99'a varan oranda benzerlikler gösterdiği saptanırken, aa düzeyinde ise \%98'e varan oranda benzerlik gösterdiği tespit edilmiştir (Şekil 3.2). Benzerlik analizleri renk matriksleri daha detaylı olarak incelendiğinde de matrikslerde bariz olarak iki farklı grubun olduğu görülmüştür. Gruplar arasındaki benzerliklerin genel olarak \%97 civarında olduğu saptanmıştır. 


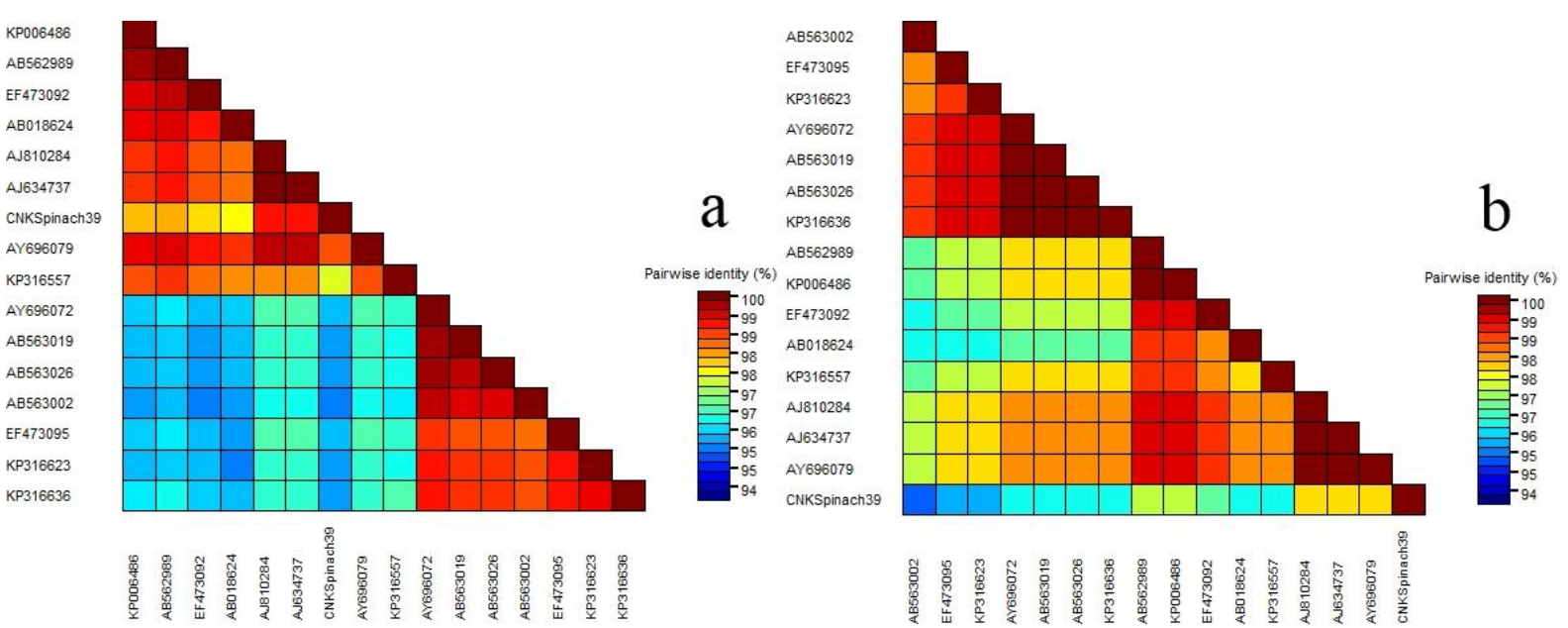

Şekil 3.2. Çanakkale ili ıspanak üretim alanlarından elde edilen CNKSpinach39 Pancar nekrotik sarı damar virüsü'nün dünya izolatları ile kılıf protein gen bölgesi nükleotit (a) ve amino asit (b) dizilimlerine göre birbirleri ile göstermiş olduğu benzerlik oranları

Nükleotit temelli gerçekleştirilen benzerlik analizleri sonucunda CNKSpinach39 BNYVV izolatı en fazla benzerliği \%99 ile AJ810284 erişim numaralı Almanya ve AJ634737 erişim numaralı Belçika izolatları ile gösterirken, en az benzerliği ise \%95 ile AB563002 erişim numaralı İtalya izolatı ile göstermiştir.

Amino asit temelli gerçekleştirilen benzerlik analizleri sonucunda CNKSpinach39 BNYVV izolatı en fazla benzerliği \%98 ile AJ810284 erişim numaralı Almanya, AJ634737 ve AY696079 erişim numaralı Belçika izolatları ile göstermiştir. En az benzerliği ise \%95 ile AB563002 erişim numaralı İtalya izolatı ile göstermiştir.

Dünyada BNYVV izolatlarının CP gen bölgesine göre gerçekleştirilen çalışmalar sonucunda da izolatların farklı seviyelerde benzerlikler gösterdiği bildirilmiştir. Polonya'da yapılan bir çalışma da şeker pancarını enfekte eden içlerinde BNYVV'nin de olduğu 4 farklı virüsün CP genine göre moleküler karakterizasyonu gerçekleştirilmiştir. Araştırmacılar bu çalışmada elde ettikleri 3 BNYVV izolatının kendi içlerinde ve dünya izolatları ile \%96-100 arasında değişen oranlarda benzerlikler gösterdiğini tespit etmişlerdir (Borodynko ve ark., 2009). Lennofors ve ark. (2005) Fransa, Almanya ve ABD'den elde ettikleri BNYVV izolatlarının CP genini temel alarak moleküler karakterizasyonlarını gerçekleştirmişlerdir. Araştırmacılar bu izolatların birbirleri ve dünya BNYVV izolatları ile \%95-100 oranlarında benzerlikler gösterdiğini belirtmişlerdir. Ayrıca araştırmacılar gerçekleştirdikleri bu çalışmanın sonucunda BNYVV izolatlarının CP geninde elde edilen sekans varyasyonlarının CP geninin tamamına dağıldığını, CP geninin herhangi bir spesifik bölgesine özel olmadığını belirtmişlerdir.

Ahmad ve ark. (2018) tarafindan Pakistan'da BNYVV enfeksiyonunun tespiti amac1 ile gerçekleştirilen başka bir çalışmada da araştırmacılar elde ettikleri bir BNYVV izolatının moleküler karakterizasyonunu gerçekleştirmişlerdir. Araştırmacılar yürüttükleri çalışmaların sonucunda dünya BNYVV izolatları ile nükleotid düzeyinde $\% 98$, amino asit düzeyinde ise \%99'a varan oranlarda izolatlar arasında benzerlikler görüldüğünü belirtmişlerdir. Ülkemizde BNYVV izolatlarının moleküler karakterizasyonu amacı ile gerçekleştirilen çalışmalar ise RNA3 genomunda bulunan P25 gen bölgesine göre gerçekleştirildiği için ülkemiz izolatları ile bir kıyaslama yapmak mümkün olmamıştır (Kutluk-Yılmaz ve ark., 2016a; 2016b). Ancak dünyada gerçekleştirilen çalışmalar ile bu çalışma kapsamında BNYVV izolatlarının CP genine göre birbirleri ile göstermiş olduğu benzerlik oranları birbirlerine paralellik göstermektedir. 
Daha öncede belirtildiği gibi ülkemizde BNYVV izolatlarının moleküler karakterizasyonlarında CP geninin genellikle kullanılmamasından dolayı genbankası veri tabanında Türk BNYVV izolatlarına ait çok sayıda sekans verisi yoktur ve olanların büyük bir çoğunluğu ise p25 ve p26 gen bölgelerine aittir. Sadece AB563026 erişim numaralı izolat CP gen bölgesine ait olup ülkemiz orijinlidir (Chiba ve ark., 2011). Bu izolatta filogenetik ve benzerlik analizlerine dahil edilmiştir. Dünya izolatları ile gerçekleştirilen filogenetik ilişkilerin araştırılması sonucunda ise CNKSpinach39 izolatı patotip B olarak bulunmuştur (Şekil 3.3).

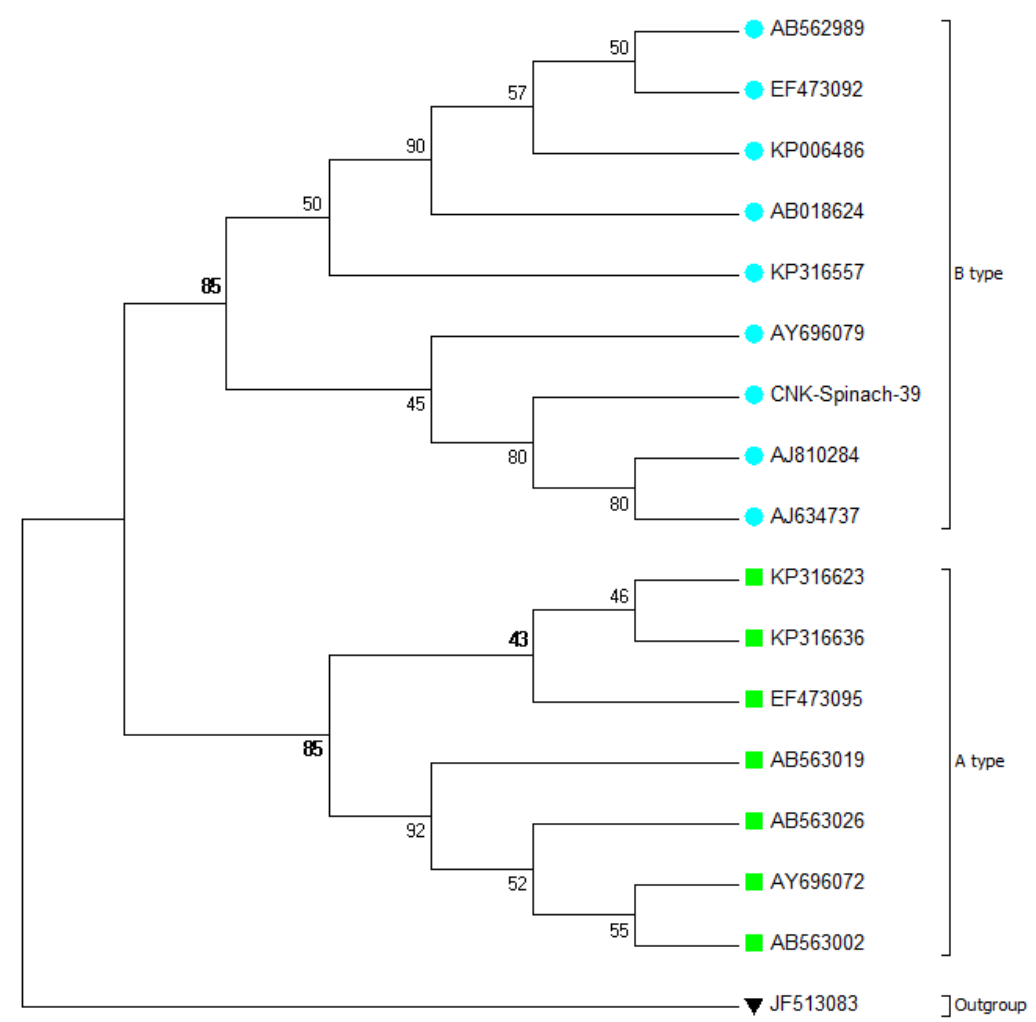

Şekil 3.3. Çanakkale ili 1spanak üretim alanlarından elde edilen CNKSpinach39 Pancar nekrotik sarı damar virüsü'nün dünya izolatları ile kılıf protein gen bölgesi nükleotit dizilimlerine göre birbirleri ile göstermiş olduğu filogenetik ilişki

Filogenetik ilişkilerin belirlenmesi amacı ile gerçekleştirilen biyoinformatik analizler sonucunda CNKSpinach39 BNYVV izolatının AB562989, EF473092, KP006486 ve KP316557 erişim numaralı Çin izolatları, AB018624 erişim numaralı Japonya, AY696079 ve AJ634737 erişim numaralı Belçika ve son olarak AJ810284 erişim numaralı Almanya izolatları ile B patotipinde yer almıştır. Ayrıca oluşturulan filogenetik ağaç daha detaylı incelendiğinde B patotipinin kendi içinde iki alt gruba ayrıldığ görülmektedir. Bu iki gruptan birincisi AB562989, EF473092, KP006486 ve KP316557 erişim numaralı Çin izolatları ve AB018624 erişim numaralı Japonya izolatından oluşurken, ikinci grubun ise AY696079 ve AJ634737 erişim numaralı Belçika ve son olarak AJ810284 erişim numaralı Almanya izolatı ile Türk izolatından oluştuğu görülmektedir. Bu bağlamda $\mathrm{B}$ patotipinde birinci alt grubun Asya orijinli izolatlardan oluştuğu, ikinci grubun ise Avrupa orijinli izolatlardan oluştuğu görülmektedir. Ancak BNYVV izolatlarının CP genine göre patotiplerinin belirlenmesinde izolatların orijinlerinin bir etkisi olmadığı söylenebilir. Çünkü Çin izolatlarının bir kısmı patotip B bulunurken, diğer bir kısmı ise patotip A olarak filogenetik ağaçta yer almıştır. Benzer şekilde bu çalışma kapsamında elde edilen CNKSpinach39 BNYVV izolatını patotip 
B grubunda yer alırken, ülkemiz orijinli olan AB563026 erişim numaralı BNYVV izolatı ise A patotipinde yer almıştır. Bu bağlamda BNYVV izolatlarının patotip oluşumlarında $\mathrm{CP}$ geninde meydana gelen varyasyonların tek etken olduğu düşünülmektedir.

Dünyada BNYVV izolatlarının filogenetik ilişkilerinin belirlenmesi amacı ile gerçekleştirilen çalışmalarda da aynı ülke izolatlarının farklı filogenetik gruplara dağılım gösterebildiği bildirilmiştir. Borodynko ve ark. (2009) tarafından Polonya'da gerçekleştirilen bir çalışmada Polonya BNYVV izolatlarının bir kısmı patotip A olarak bulunurken, bazıları ise patotip B olarak bulunduğu bildirilmiştir. Lennefors ve ark. (2005) tarafından dünyanın farklı ülkelerinden elde edilen BNYVV izolatlarının moleküler karakterizasyonları amacı ile gerçekleştirilen bir başka çalışmada da izolatların A ve B patotiplerine ait olduğu bildirilmiştir. Ayrıca Lennefors ve ark. tarafından gerçekleştirilen bu çalışmada da Çin izolatlarının bir kısmının A, diğer bir kısmının ise B patotipine ait olduğu bildirilmiştir. $\mathrm{Bu}$ bağlamda dünyada gerçekleştirilen farklı çalışmalardan elde edilen sonuçlar da bu çalışma kapsamında elde edilen sonuçları destekler niteliktedir.

\section{Sonuç}

Gerçekleştirilen bu çalışma Çanakkale ili ve ilçeleri ıspanak üretim alanlarında BNYVV enfeksiyonu tespit edilerek, moleküler olarak karakterizasyonu gerçekleştirilmiştir. Moleküler karakterizasyon çalışmaları sonucunda bizim bilgilerimize göre ülkemizde ilk kez BNYVV'nin B patotipi tespit edilmiştir. Bundan sonra gerçekleştirilecek çalışmalarda ülkemiz BNYVV izolatlarının tüm genom analizlerinin yapılarak genom segmentleri arasındaki rekombinasyon olayları araştırılmalıdır. Ayrıca BNYVV'e karşı konukçu dayanıklılığına yönelik araştırmalara da ağırlık verilmelidir.

\section{Teșekkür}

$\mathrm{Bu}$ çalışma birinci yazarın yüksek lisans tezinden üretilmiş olup, Çanakkale Onsekiz Mart Üniversitesi Bilimsel Araştırma Projeleri Koordinasyon birimince desteklenmiştir. Proje Numaras1: FYL-2018-2545. 


\section{Kaynakça}

Abe H., Tamada T., 1986. Association of Beet Necrotic Yellow Vein Virus with Isolates of Polymyxa Betae Keskin. Annls. Phytopath. Soc. Jap., 52: 235-247.

Ahmad S., Ali A., Ahmad M., Ullah N., Afridi U.K., Bostan N., Qureshi R., Tawwab S., Ahmad I., Zubair M., 2018. Characterization of beet necrotic yellow vein virus in Pakistan. Journal of Plant Pathology, 100 (2): 357-357.

Borodynko N., Rymelska N., Hasiów-Jaroszewska B., Pospieszny H., 2009. Molecular characterization of three soil-borne sugar beet-infecting viruses based on the coat protein gene. Journal of Plant Pathology, 191-193.

Chiba S., Kondo H., Miyanishi M., Andika I.B., Han C., Tamada T., 2011. The evolutionary history of beet necrotic yellow vein virus deduced from genetic variation, geographical origin and spread, and the breaking of host resistance. Mol. Plant Microbe Interact., 24: 207-218.

Clark M. F., Adams A. N., 1977. Characteristics of the microplate method of enzyme-linked immunosorbent assay for the detection of plant viruses. Journal of General Virology, 34 (3): 475-483.

Erbay E., 2012. Gediz Havzası Ispanak Üretim Alanlarında Görülen Virüs Hastalıklarının Belirlenmesi Üzerine Araştırmalar. Ege Üniversitesi, Fen Bilimleri Ens., Yüksek Lisans Tezi.

Gökdağ S., Karanfil A., Korkmaz S., 2016. Çanakkale ili ıspanak alanlarındaki şalgam mozaik virüsü ve hıyar mozaik virüsü varlığının belirlenmesi. BAHÇE Özel sayı: VII. Ulusal Bahçe Bitkileri Kongresi Bildirileri-Cilt II: Sebzecilik-Bağcılık-Süs Bitkileri, 166-170.

Gümüş M., Erbay E., Erkan Paylan I.C., 2013. Occurrence of Viruses Infecting Spinach in Western Anatolia of Turkey: The First Field Survey Report. Journal of Food Agriculture \& Environment, 12 (1): 272-275.

Güngör M., Uzunbacak H., Kutluk Y1lmaz N.D., Şevik M.A., 2017. Samsun ili 1spanak üretim alanlarında enfeksiyon oluşturan virüslerin belirlenmesi. Anadolu Tarım Bilim. Derg./Anadolu J Agr Sci, 32: 164-168. 
Harju V.A., Mumford R.A., Blockley A., Boonham N., Clovert G.R.G., Weekes R., Henry C.M., 2002. Occurrence in the United Kingdom of Beet necrotic yellow vein virus isolates which contain RNA 5. Plant Pathol., 51: 811.

Karanfil A., Gökdağ S., Korkmaz S., 2016. Çanakkale ili ve ilçeleri 1spanak üretim alanlarındaki Pancar nekrotik sarı damar virüsü (Beet necrotic yellow vein virus; BNYVV) enfeksiyonunun araştırılması. Uluslararası Katılımlı Türkiye VI. Bitki Koruma Kongresi, 592, 5-8 Eylül, Konya.

Koenig R., Lennefors B.L., 2000. Molecular analyses of European A, B and P Type Sources of Beet Necrotic Yellow Vein Virus and Detection of The Rare P Type in Kazakhstan. Arch Virol., 145: 1561-1570.

Koenig R., Lüdecke P., Haeberle A.M., 1997. Detection and Characterization of a Distinct Type of Beet Necrotic Yellow Vein Virus RNA 5 in a Sugar Beet Growing Area in Europe. Arc Virol., 142: 1499-1504.

Kruse M., Koenig R., Hoffman A., Kaufmann A., Commandeur U., Solevyev A.G., Savenkov I., Burgermeister W., 1994. Restriction Fragment Length Polymorphism Analysis of Reverse Transcription-PCR Products Reveals the Existence of Two Major Strain Groups of Beet Necrotic Yellow Vein Virus. J Gen Virol., 75: 1835-1842.

Kumar S., Stecher G., Tamura K., 2016. MEGA7: Molecular evolutionary genetics analysis version 7.0 for bigger datasets. Molecular Biology and Evolution, 33: 1870-1874.

Kutluk-Y1lmaz N.D., Arli-Sokmen M., Kaya R., Sevik M.A., Tunali B., Demirtas S., $2016 a$. The widespread occurrences of Beet soil borne virus and RNA-5 containing Beet necrotic yellow vein virus isolates in sugar beet production areas in Turkey. Eur J Plant Pathol. 144(2): 443-455.

Kutluk-Yılmaz N.D., Kaya-Altop E., Phillippo C.J., Mennan H., 2016b. New Natural Weed Host Raphanus raphanistrum L. (Brassicaceae) for Beet Necrotic Yellow Vein Virus and Its Vector Polymyxa betae Keskin. Turkish Journal of Agriculture and Forestry, 40: 120-126.

Lennefors B.L., 2006. Molecular Breeding for Resistance to Rhizomania in Sugar Beets. Swedish University of Agricultural Sciences, 2006. Doctoral Thesis, 41pp. Uppsala. 
Lennefors B.L., Savenkov E.I., Mukasa S.B., Valkonen J.P.T., 2005. Sequence Divergence of Four Soilborne Sugarbeet-Infecting Viruses. Virus Genes, 31 (1): 57-64.

Li R., Mock R., Huang Q., Abad J., Hartung, J.; Kinard, G., 2008b.A reliable and inexpensive method of nucleic acid extraction for the PCR-based detection of diverse plant pathogens. Journal of Virological Methods, 154 (1-2): 48-55.

Li M., Liu T., Wang B., Han C., Li D., Yu J., 2008a. Phylogenetic analysis of Beet necrotic yellow vein virus isolates from China. Virus Genes, 36 (2): 429-432.

Meunier A., Schmit J.F., Bragard C., 2005. Comparison of the beet necrotic yellow vein virus P75 nucleotide sequences of Belgian type A and type B sources. Virus Res., 108 (1-2): $15-22$.

Miyanishi M., Kusume T., Saito M., Tamada T., 1999. Evidence for three groups of sequence variants of beet necrotic yellow vein virus RNA 5. Arch Virol., 144 (5): 879-892.

Muhire B.M., Varsani A., Martin D.P., 2014. SDT: A virus classification tool based on pairwise sequence alignment and identity calculation. PLoS One, 9 (9): 1-8.

Özgör O.E., 1995. Türkiye Şeker Pancarı Hastalıkları. Türkiye Şeker Fabrikaları A.Ş. Genel Müdürlüğ̈̈, 218: 33-47.

Putz C., Merdinoğlu O., Lemaire O., Stocky G., Valentin P., Wiedemann S., 1990. Beet Necrotic Yellow Vein Virus, Causal Agent of Sugar Beet Rhizomania. Rew .Pl. Path., 69 (5): 247-254.

Rush C.M., Heidel G.B., 1995. Furovirus Diseases of Sugar Beets in the United States. Plant Dis, 79 (9): 868-875.

Schirmer A., Link D., Cognat V., Moury B., Beuve M., Meunier A., Bragard C., Gilmer D., Lemaire O., 2005. Phylogenetic analysis of isolates of Beet necrotic yellow vein virus collected worldwide. Journal of General Virology, 86: 2897-2911.

Tamada T., Abe H., Saito M., Kiguchi T., Harada T., 1989. Production and pathogenicity of isolates of Beet necrotic yellow vein virus with different numbers of RNA components. J Gen Virol. 70: 3399-3409.

Tamada T., Baba T., 1973, Beet Necrotic Yellow Vein Virus from "Rhizomania" Affected Sugar Beet in Japan. Annls. Phytopath. Soc. Japan, 39: 325-352. 
Whitney E.D., Duffus J.E., 1991. Rhizomania (Beet Necrotic Yellow Vein Virus).

Compendium of Beet Diseases and Insects, APS Pres, 76p, USA.

Yılmaz N.D., Erkan S., 2003. Şeker Pancarı'nda Rhizomania Hastalığı. OMÜ Ziraat Fakültesi Dergisi, 20 (1): 64-72.

Zhuo N., Jiang N., Zhang C., Zhang Z.Y., Zhang G.Z., Han C.G., Wang Y., 2015. Genetic diversity and population structure of beet necrotic yellow vein virus in China. Virus Res., 205: 54-62. 